\title{
Epidemiological aspects of schistosomiasis in workers of the Movement of Landless Rural Workers
}

\author{
Genilde Gomes de Oliveira ${ }^{[1],[2], ~ A ̂ n g e l a ~ M a r i a ~ d a ~ S i l v a ~}{ }^{[1]}$, Amélia Maria Ribeiro de Jesus[1],[3], \\ Marco Antônio Prado Nunes ${ }^{[1]}$, Jenisson Oliveira Conceição ${ }^{[1]}$, Flávia Oliveira Costa ${ }^{[1]}$, \\ José Fernandes de Araújo ${ }^{[1]}$ and Enaldo Vieira de Melo ${ }^{[1]}$
}

[1]. Departamento de Medicina, Hospital Universitário, Universidade Federal de Sergipe, Aracaju, SE. [2]. Faculdade Estácio de Sergipe, Aracaju, SE. [3]. Instituto de Investigação em Imunologia, Institutos Nacionais de Ciência e Tecnologia, Conselho Nacional de Desenvolvimento Científico e Tecnológico, Brasília, DF.

\begin{abstract}
Introduction: Schistosomiasis is endemic in 74 countries and is considered a serious public health problem in some locations. Methods: A transverse study was performed of 13 landless settlements in southern Sergipe from February to December 2009. The study included 822 settlers, of whom 601 underwent stool testing. Results: The prevalence of schistosomiasis in landless workers was $4.3 \%$. The population has a low education level, and basic sanitation services are not available to all residents. Conclusions: The prevalence of schistosomiasis was low in the population and among different settlements, possibly because of different forms of water use by the settlers.
\end{abstract}

Keywords: Schistosomiasis. Intestinal parasites. Settlements.

Schistosomiasis is caused by Schistosoma mansoni infection and is registered in 74 countries. Schistosomiasis is considered a serious public health problem in many areas of Brazil. Government actions are required to improve sanitation, control snails with molluscicides, treat infected persons, and educate at-risk populations ${ }^{1}$.

Schistosomiasis is a disease with global impact that remains difficult to control centuries after its discovery because it involves interactions between government agencies, the planning and implementation of sanitation, the use of molluscicides to combat snails, drugs to treat infected people, and education regarding the deposition of feces ${ }^{1}$.

The Brazilian social movement known as the Movement of Landless Rural Workers was created in the 1980s with the aim of promoting agrarian reform for landless peasants relying on unproductive properties. However, these settlements do not have an adequate health infrastructure, favoring the emergence of waterborne diseases ${ }^{2}$.

To verify the presence of Schistosoma mansoni in the stools of landless settlers in riverside towns of southern Sergipe, Brazil, to evaluate the effect of socio-environmental factors on the spread of this parasite, and to characterize the clinical forms of the infected patients, we developed a cross-sectional study of 13 settlements within the region from February to December 2009 (Figure 1).

\footnotetext{
Address to: Dra. Genilde Gomes de Oliveira. Depto de Medicina/HU/UFS Rua Claúdio Batista s/n, Bairro Sanatório, 49140-000 Aracaju, SE, Brasil. Phone: 5579 2105-1818/79 9989-9948; Fax: 5579 3259-3491

e-mail: d.genilde@ig.com.br

Received 12 October 2011

Accepted 21 February 2013
}

The study population included those aged 2 to 65 years and encompassed 227 households from 13 settlements. The clinical epidemiological survey was conducted in situ through home visits. For the study of Schistosoma mansoni eggs, the first 3 stool samples collected on alternate days were packed in a TFTest ${ }^{\circledR}$ Kit (Three Fecal Test; Imunoassay Ltd, Brazil). This set comprises three tubes, and the fecal samples were preserved under analytical conditions for 30 days $^{3}$. The samples were sent for analysis at the laboratory of the University Hospital of the Federal University of Sergipe. All infected patients were treated.

From the 601 examinations, a prevalence rate of $4.3 \%$ was obtained for S. mansoni. Of the 13 settlements, $8(61.5 \%)$ were positive for $S$. mansoni, and the positivity rate varied from 0 to $22.2 \%$ among settlements.

Among infected individuals aged 3 to 48 years, $69.2 \%$ were male subjects, and there were no differences in prevalence between adults and children younger than 14 years. All individuals with $S$. mansoni in the feces showed the intestinal form of the disease. The most common clinical manifestations were abdominal pain $(84.6 \%)$, headache $(65.4 \%)$, anorexia (42.3\%), cough (34.6\%), and nausea (30.8\%). Abdominal pain was the only symptom with a statistically significant association with infection $(\mathrm{p}<0.01)$. Among the settlers, $54.6 \%$ worked in agriculture, $71.7 \%$ bathed in the river, and $48.8 \%$ attended school. Furthermore, $69.3 \%$ attended elementary school, $26.9 \%$ were illiterate, and $3.8 \%$ had incomplete secondary education (Table 1).

The incidence of other parasites was also examined in this study: Ascaris lumbricoides, Necator americanus, Entamoeba histolytica, and Giardia intestinalis were identified in 13 settlements, Trichuris trichiura in 11, Strongyloides stercoralis in 7, Enterobius vermicularis in 2, and Taenia solium, Taenia saginata, and Hymenolepis nana in 1. 


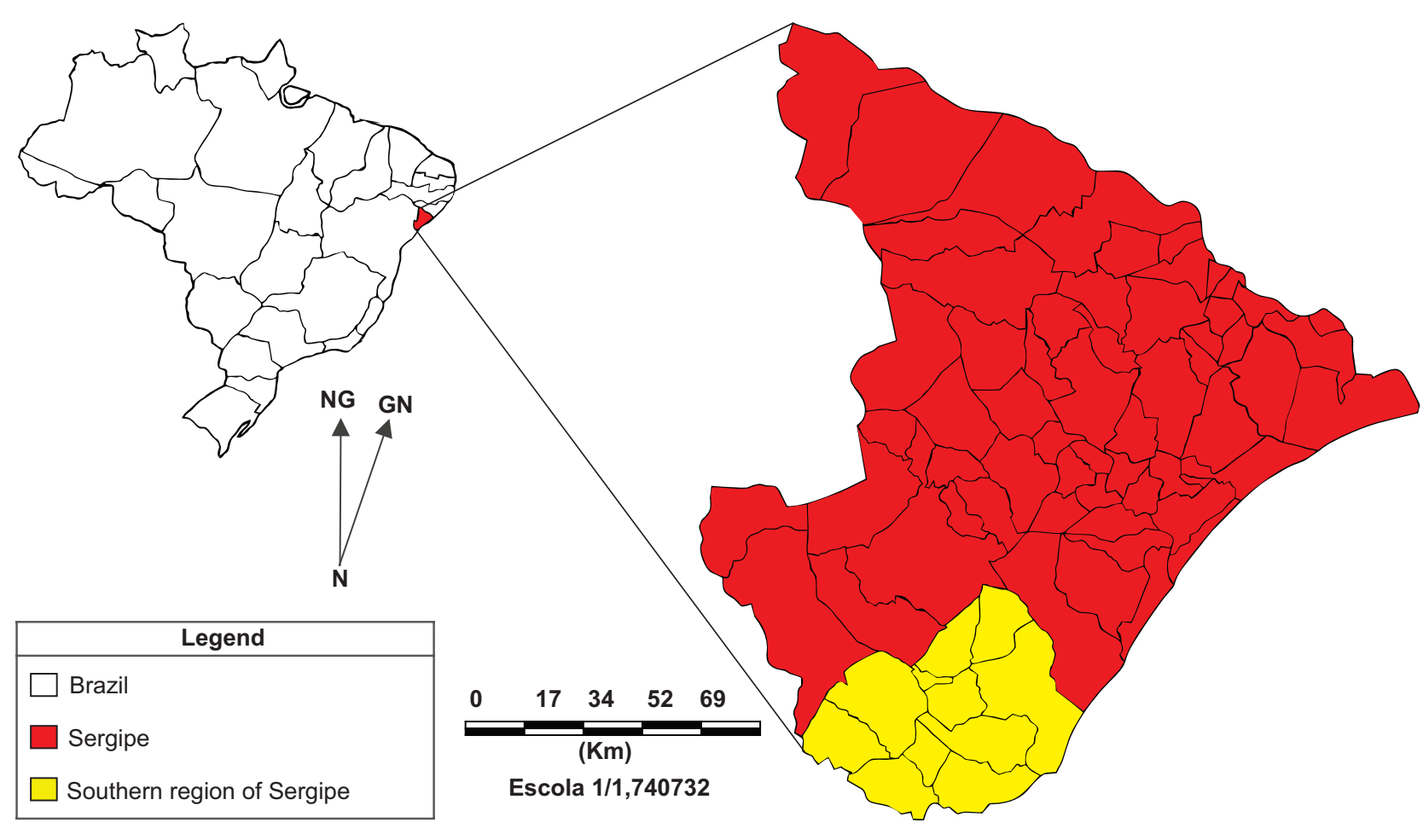

FIGURE 1 - Study Area in the State of Sergipe. GN: geographic north; NG: northern grid; N: north.

TABLE 1 - Distribution of sociodemographic variables of the Landless Settlers in the southern region of the State of Sergipe, Brazil, 2009.

\begin{tabular}{|c|c|c|c|c|c|c|}
\hline \multirow[b]{2}{*}{ Variable } & \multicolumn{6}{|c|}{ Schistosoma mansoni } \\
\hline & $\mathrm{n}$ & $\%$ & $\mathrm{n}$ & $\%$ & $\mathrm{n}$ & $\%$ \\
\hline \multicolumn{7}{|l|}{ Gender } \\
\hline male & 302 & 50.2 & 18 & 6.0 & 284 & 94.0 \\
\hline \multicolumn{7}{|c|}{ Attend school } \\
\hline yes & 293 & 48.8 & 16 & 5.5 & 277 & 94.5 \\
\hline no & 308 & 51.2 & 10 & 3.2 & 298 & 96.8 \\
\hline \multicolumn{7}{|c|}{ Work in agriculture } \\
\hline \multicolumn{7}{|c|}{ Bathe in the river } \\
\hline yes & 431 & 71.7 & 17 & 3.9 & 414 & 96.1 \\
\hline no & 170 & 28.3 & 9 & 5.3 & 161 & 94.7 \\
\hline
\end{tabular}

Regions with a prevalence rate higher than $10 \%$ are considered of medium to high endemic prevalence, and those with a prevalence rate of less than $10 \%$ are considered of low endemicity. Most of the infected individuals presented the clinical intestinal form or were asymptomatic or oligosymptomatic ${ }^{4,5}$. In this study, the prevalence rate was $4.3 \%$, characterizing the population as low endemicity. However, this does not minimize the importance of the data because positive individuals contaminate water reservoirs due to a lack of local health infrastructure.

The infection prevalence was similar among adults and children, in contrast to other studies that have shown a higher prevalence and intensity of infection among children in endemic 
areas $^{6}$. Male subjects were more frequently affected, although previous studies have indicated an equivalent prevalence for both sexes and that the severity of infection depends on the frequency of contact with contaminated water?

Sociodemographic analysis revealed a high frequency of bathing in the river. Among the individuals participating in this activity, $3.9 \%$ had $S$. mansoni in the feces, which represents a high risk of contamination of water sources ${ }^{6}$.

Agricultural labor and environmental conditions are additional risk factors for the transmission of schistosomiasis; the irrigation system attracts snails, and cercariae can travel to the plantations. In addition, the washing of vegetables and fruits in the river may constitute continuous exposure ${ }^{8}$.

The prevalence of infection ranged from 0 to $22.2 \%$ among settlements, even when located in the same county. This diversity was due to the focal epidemiology and dispersion of populations with high rates of infection in children?.

In the settlement Bela Vista, $22.2 \%$ of the subjects were infected. Of these, $58.3 \%$ were children, possibly due to their longer contact with contaminated water during bathing in rivers and leisure ${ }^{6}$.

No positive schistosomiasis cases were found in the settlements Paulo Freire II, Rosa Luxemburg, April 17, and Roseli Nunes, all near the town of Estancia. The focal character of the disease may have contributed to these data ${ }^{9,10}$.

The present study did not quantify the parasite load. Some authors have defined high parasite load as essential for the development of severe forms of schistosomiasis. However, others argue that this is not the only factor because only a few develop hepatosplenic disease when living under the same epidemiological conditions in hyperendemic areas ${ }^{7}$, while the intestinal form is more prevalent ${ }^{11}$. In isolated foci, schistosomiasis is characterized by an almost complete absence of severe forms, which are more commonly found in hyperendemic areas ${ }^{7}$.

The control of schistosomiasis has been one of the most difficult undertakings of the Public Health Services. The importance of the disease is not restricted to its prevalence and geographic distribution but also incorporates issues of resistance of mollusks to molluscicides, precarious housing conditions, and basic sanitation and economic activities related to water use ${ }^{12}$.

Although the region currently presents a low prevalence, it remains necessary for the managers of the Public Health Service to develop public policies to improve sanitation and to fully adopt the guidelines of the Unified Health System (Sistema Único de Saúde). This will prevent the spread of S. mansoni and subsequent conversion to a hyperendemic region.

It is likely that the low prevalence observed in this study is indicative of the absence of recent schistosomiasis transmission. Thus, we suggest that additional diagnostic methods, such as serological tests for the improved evaluation of long-term epidemiological control programs, should be utilized to confirm the data presented in this study. Immunological methods are more sensitive but are also more expensive and may cross-react with other helminth infections ${ }^{5,13,14}$.

The prevalence of schistosomiasis among landless laborers in southern Sergipe is relatively low when compared to that of the entire state. Despite the low prevalence and mild clinical form of (intestinal) infection, the presence of $S$. mansoni infection in $61.5 \%$ of the settlements is worrisome because these migratory populations may carry the disease to other regions. The social and environmental conditions of the settlers, including primary education level, agriculture, recreational activities in rivers, and poor sanitation, were very similar in southern Sergipe.

\section{CONFLICT OF INTEREST}

The authors declare that there is no conflict of interest.

\section{REFERENCES}

1. Magalhães TE, Leite FL. Ecologia de paisagem, dinâmica das populações e complexos eco-patogênicos: definição eco epidemiológica da esquistossomose mansônica na Bacia Hidrográfica do Rio Barra Mansa. Paper presented at: VIII Congresso de Ecologia do Brasil; 2007. [Cited 2009 December 10] 2009. Available at: http://www.seb-ecologia.org.br/viiiceb/pdf/130.pdf/.

2. Cintra MCB. A trajetória do Movimento dos Trabalhadores Rurais Sem Terra (MST) em Sergipe 1985-1997. 1999. [Masters Dissertation]. [Aracaju]: Universidade Federal de Sergipe; 1999.

3. Hoshino-Shimizu S, Gomes JF, Dias LCS. Parasitos intestinais: técnicas tradicionais e conjuntos comerciais. J. Bras Patol 2001; 37 (supl): 21.

4. Resendes APC, Santos RS, Barbosa CS. Internação hospitalar e mortalidade por esquistossomose mansônica no Estado de Pernambuco, Brasil, 1992/2000. Cad Saude Publica 2005; 21:1392-1401

5. Dias LCS, Glasser CM, MarçaL Jr O, Bonesso PIP. Epidemiology of schistosomiasis mansoni in a low endemic area. Cad Saude Publica 1994; 10 (supl 1 II):254-260.

6. Doehring E. Schistosomiasis in Childhood. Eur Pediatr 1988; 147:2-9.

7. Bina JC, Prata A. A evolução natural da esquistossomose mansoni em uma área endêmica. Aspectos peculiares da infecção por S. mansoni. Salvador: Centro Didático e Editorial da Universidade Federal da Bahia. 1984. p. 13-33.

8. Barbosa CS, Barbosa FS. Padrão epidemiológico da Esquistossomose em Comunidade de Pequenos Produtores Rurais de Pernambuco Brasil. Cad Saude Publica 1998; 14:129-137.

9. Gryseels B, Polman K, Clerinx J, Kestens L. Human Schistosomiasis. Lancet 2006; 368:1106-1118.

10. Ministério da Saúde. Portal da Saúde. Coordenação de Vigilância das Doenças Transmitidas por Vetores [Internet] Brasília: Ministério da Saúde; 2009. [Cited 2009 December 10]. Available at: <http://portal.saude.gov.br/portal/saude/ profissional/area.cfm?id_area $=1551 /$.

11. Barbosa CS, Domingues ALC, Abath F, Montenegro SML, Guida U, Carneiro J, et al. Epidemiologia da Esquistossomose Aguda na Praia de Porto de Galinhas Pernambuco - Brasil. Cad Saude Publica 2001; 17:725-728.

12. Ferreira ILM, Silva TPT. Mortalidade por Esquistossomose no Brasil: 19802003. Rev Patol Trop 2007; 36:67-74.

13. Dias JCP. Problemas e possibilidades de participação comunitária no controle das grandes endemias no Brasil. Cad Saude Publica 1998; 14 (supl II):19-37.

14. Jurberg AD, Oliveira AA, Lenzi HL, Coelho PMZ. A New Miracidia Hatching Device for Diagnosing Schistosomiasis. Mem Inst Oswaldo Cruz 2008; 103:112-114. 